\title{
RADIOCARBON CHRONOLOGY OF PALEOGEOGRAPHIC EVENTS OF THE LATE PLEISTOCENE AND HOLOCENE IN RUSSIA
}

\author{
P. A. KAPLIN, A. A. SVITOCH and O. B. PARUNIN
}

Laboratory of Recent Sediments and Pleistocene Paleogeography, Moscow State University Leninske Gory, Moscow 119899 Russia

\begin{abstract}
C}$ chronology of Late Pleistocene paleogeographical events in the Black Sea-Caspian Sea region shows that the following transgressions partly correlate with each other: Karangat and Khazarian; Neo-Euxinian and Khvalyn; Holocene and Neo-Caspian. The main climatic events were synchronous in intercontinental Siberia. In the far eastern region, the Middle-Wisconsinan transgression is reflected by Chukotka and western Kamchatka terraces and by submerged ancient shorelines in Primorye.
\end{abstract}

\section{INTRODUCTION}

A multitude of radiocarbon dates has demonstrated that the ${ }^{14} \mathrm{C}$ method, though presently most widely employed for dating Late Pleistocene and Holocene sedimentation events, sometimes disagrees with age estimates determined by other methods. For Late Pleistocene dates, significant discrepancies have been observed among thermoluminescence, ${ }^{14} \mathrm{C}$ and uranium-series data caused by the different bases, technology and error estimations of each method. Development of absolute chronologies for each method may yield sufficient agreement among each. In this paper, we evaluate ${ }^{14} \mathrm{C}$ results that pertain to Late Pleistocene and Holocene events in the Caspian-Black Sea region, interior Eurasia and the Russian far eastern coast (Fig. 1) with the aim of making regional correlations in intracontinental and coastal settings.

\section{METHODS}

The Laboratory of Recent Sediments and Pleistocene Paleogeography, Moscow State University, employs liquid scintillation ${ }^{14} \mathrm{C}$ analysis. We prepared marine biogenic carbonates by thermal purification (to $500^{\circ} \mathrm{C}$ ) under continuous evacuation until degassing of allogenic $\mathrm{CO}_{2}$ and organics was complete. ${ }^{14} \mathrm{C}$ analysis was performed by liquid scintillation counting of benzene with $0.1 \mathrm{~g} \mathrm{liter}^{-1}$ POPOP $+0.4 \mathrm{~g} \mathrm{liter}^{-1}$ PPO scintillants.

\section{THE LATE PLEISTOCENE IN THE CASPIAN-BLACK SEA REGION}

Dynamic Late Pleistocene paleogeographical changes occurred in the area between the Black Sea and the Caspian Sea, involving periodic connections between these basins and sharp biotic fluctuations. Currently, most workers recognize the following sequence of events in the Black Sea region: 1) Karangat transgression; 2) Post-Karangat epoch; 3) Burgas-Gugilovo deposits of Manych; 4) Surozh transgression; 5) Neo-Euxinian regression; 6) Holocene (Flandrian) transgression with the Kalamit maximum. In the Caspian region, the following sequence is inferred: 1) Khazar transgression; 2) Atel regression; 3) Early Khvalyn transgression; 4) Yenotaevka regression; 5) Late Khvalyn transgression; 6) Mangyshlak regression; 7) Neo-Caspian transgression with the Daghestan maximum.

\section{Black Sea Regional Chronology}

${ }^{14} \mathrm{C}$ dates have been obtained on Late Pleistocene Karangat, Neo-Euxinian and Paleo-Euxinian marine sediments from coastal Bulgaria. Analysis of Corbulla gibba shell carbonates collected from 


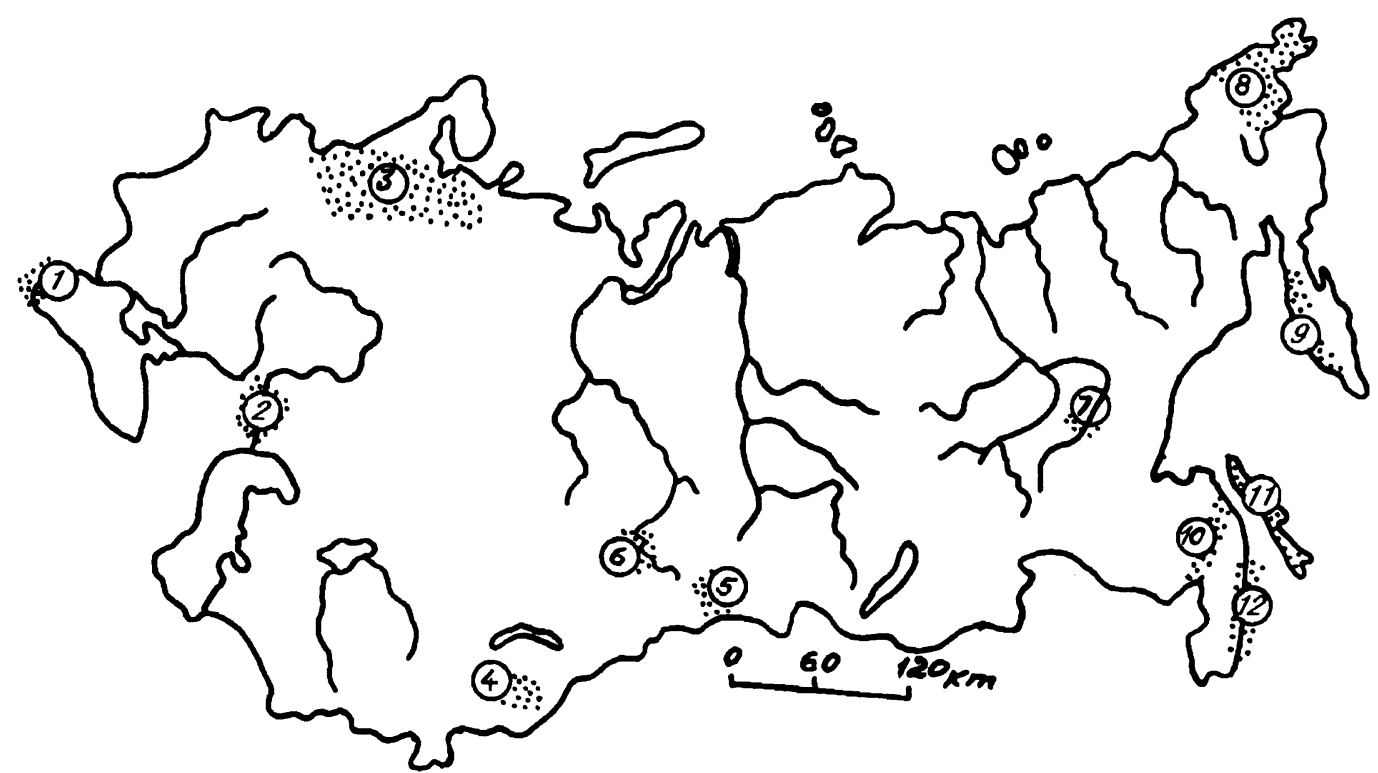

Fig. 1. General scheme of the regions under study: 1. coast and shelf of Bulgaria; 2. Lower Povolzhie; 3. north of Russian plain; 4. Issyk-Kul Lake; 5. Gornyi Altai; 6. Priobie Plateau; 7. Aldan; 8. Chukotka; 9. western Kamchatka; 10. lower Primorye; 11. Sakhalin; 12. coast and shelf of the Sea of Japan

a terrace near Varna yielded a date of $23,880 \pm 490$ BP (MGU-1173). Stratigraphic relations indicate an Upper or Lower Karangat age. Corbulla gibba is also found on the Black Sea shelf in Lower Karangat sediments; pollen spectra of these deposits indicate a climatic transition from cool dry to warm humid conditions. It is inferred that this transition characterizes the period of Karangat transgression. However, this maximum was dated from sediments on the Varna Lake shore at $39,100 \pm 900 \mathrm{BP}(\mathrm{Ki}-628)$ and 30,200 $\pm 950 \mathrm{BP}(\mathrm{Ki}-629)$ (Semenenko, Kogomijieva and Kovalyukh 1976). It must be noted that the ${ }^{14} \mathrm{C}$ results disagree strongly with geological data and uraniumseries dates (85-115 ka BP; Arslanov et al. 1983).

${ }^{14} \mathrm{C}$ dates of Neo-Euxinian shelf sediment cores range from 8 to $28 \mathrm{ka}$ BP. The most reliable dates for the Neo-Euxinian, supported by paleontological data, lie within the range, 11-17 ka BP. On the coast of the Azov Sea and eastern Black Sea, the Neo-Euxinian has been dated at 9.5-22 ka BP (Balabanov and Izmailov 1989).

Shell carbonates of Mediterranean immigrant species (Mytilus galloprovincialis, Dreissena polymorpha and Monodacna caspia) from Burgaz-Vitiazevo sediments on the exposed outer shelf of Bulgaria were dated at $7020 \pm 110 \mathrm{BP}$ (MGU-1174) and $7040 \pm 200 \mathrm{BP}$ (MGU-676). These results indicate that the Holocene transgression started no later than $7000 \mathrm{BP}$; it may have begun earlier, because biostratigraphic data relate the onset of the transgression with immigration to the Black Sea of the euryhaline Cardium edule, the entry of which occurred earlier than that of Mytilus galloprovincialis.

We obtained sufficient reliable dates to correlate sediments of the Kalamit maximum in strata on both the Bulgarian shelf and coast. In the type section of the marine Holocene on the coast, the Nesebr quarry, shell carbonates (Chiona gallina, Donax trunculus, Cardium edule, Mytilus lineatus) date sediments of the transgression maximum at $4300-5600 \mathrm{BP}$. Outer-shelf Kalamit sediments date at $4390-5110 \mathrm{BP}$. Shallow sediments of low abrasion-accumulation coastal terraces at Tuzla Lake 
and Shabla Cape are dated at 2-3 ka BP, and appear to fix the upper age limit of the Holocene transgression maximum. Similar ${ }^{14} \mathrm{C}$ results were obtained by analysis of Kazantip sediments of the Azov Sea, supporting biostratigraphic data (Nevesskaya 1965) regarding contemporaneous deposition of Kazantip (Azov Sea) and Kalamit (Black Sea) sediments in the Azov and Black Sea areas, respectively. The most recent Holocene sediments (Nymphean) of the Bulgarian coast, sampled at the mouth of the Botovaya River, yielded a shell carbonate (Donax trunculus, Ostrea edulis, Cardium edule) date of $290 \pm 90$ BP (MGU-1182).

In summary, dating of Late Pleistocene marine sediments from the Bulgarian shelf and coast suggest the following sequence: Karangat transgression ( $>30 \mathrm{ka} \mathrm{BP})$; Post-Karangat epoch $(18-12$ ka BP); regressional Neo-Euxinian basin (17-11 ka BP); onset of Holocene (Flandrian) transgression (9-7 ka BP); Kalamit transgression maximum (5-3 ka BP); stabilization after 2 ka BP.

\section{Caspian Sea Regional Chronology}

The chronology of Caspian eustatic changes is unclear despite numerous ${ }^{14} \mathrm{C}$ dates. Early Khvalyn sediments are dated at 11-18 ka BP, with a mean age of $c a .13 \mathrm{ka} \mathrm{BP}$ (ignoring extreme values). Upper Khvalyn sediments are dated to 9-14 ka BP, mean value ca. $12 \mathrm{ka}$ BP. These strata are practically undifferentiated by ${ }^{14} \mathrm{C}$ dating. Neo-Caspian sediment dates range from $<1000-8000 \mathrm{BP}$; mean age is $2300 \mathrm{BP}$. In summary, the timing of Late Pleistocene-Holocene events is inferred as follows: Khazar transgression ( $>28 \mathrm{ka} \mathrm{BP}$ ); Early Khvalyn transgression (18-11 ka BP); Late Khvalyn (14-9 ka BP); Neo-Caspian ( $<8$ ka BP).

Differing interpretations of the chronology exist. Dates of the end of the Khazar transgression are underestimated and do not match the Caspian paleogeographic record. Lower Khvalyn sediment dates are also controversial, as some workers believe that these results are significantly underestimated because of enrichment of shells by exotic uranium from groundwater. The mechanism for this enrichment is unknown, however, and Khvalyn sands are capped by virtually impermeable clays. It is inferred that the Khvalyn transgression was a single event consisting of two major phases interrupted by the brief Yenotaevka regresssion ( $c a .10 \mathrm{ka} \mathrm{BP}$ ).

Of all dates, only Neo-Caspian sediments have good agreement between ${ }^{14} \mathrm{C}$ results and geological data. The latter suggest that the Neo-Caspian transgression, the last major transgressive cycle of the regresssive Khvalyn Sea, occurred after 8000 BP and peaked ca. 6-5 ka BP.

\section{Black Sea-Caspian Sea Correlation}

Correlation of paleogeographic events between Black Sea and Caspian Sea regions reveals several associations. The Karangat transgression partially coincides with the end of the Khazar transgression, the Post-Karangat epoch with the Atelian regression, the Early Khvalyn transgression with the Neo-Euxinian basin and the Late Khvalyn and Neo-Caspian transgressions with the Holocene Black Sea basin (Fig.2).

It appears that ${ }^{14} \mathrm{C}$ results provide only partial correlations between the two basins, unlike geological and geomorphological data. There is correspondence in dates between Karangat and Khazar transgressions, Burgas-Gudilovo and Atelian formations, and Neo-Caspian and Paleo-Euxinian sediments. Deposits of the Black Sea Surozh transgression appear to be contemporaneous with sediments of the Early Khvalyn transgression, but not older as ${ }^{14} \mathrm{C}$ results indicate. Also, ${ }^{14} \mathrm{C}$ data that indicate a Neo-Euxinian-Late Khvalyn correlation are not supported by field data. 


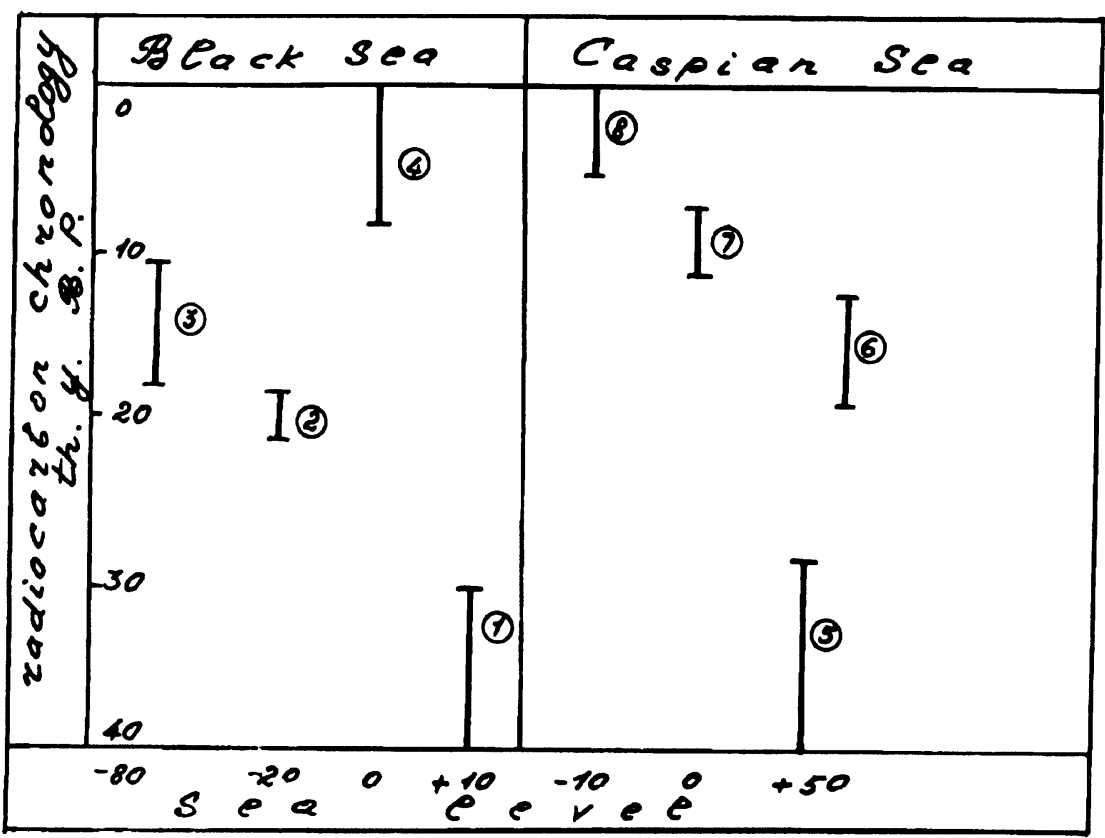

Fig. 2. Correlation of Black Sea-Caspian paleogeographical events: 1. Karangat transgression; 2. PostKarangat period; 3. Neo-Euxinian basin; 4. Holocene transgression; 5. Khazar transgression; 6. Early Khvalyn transgression; 7. Late Khvalyn transgression; 8. Neo-Caspian transgression

\section{PALEOGEOGRAPHICAL CORRELATIONS IN INTRACONTINENTAL REgIONS}

Detailed correlations of paleogeographic events are not possible for the entire intracontinental Quaternary period because of the nature of continental deposits. However, clearly defined sediments that mark the second Late Pleistocene cooling (Late Valdai, Sartan, Late Würm, Late Wisconsin) have been recognized. At this time $(25,000 \pm 3000 \mathrm{BP}$; MGU-58), the Late Valdai (Ostashkovo) glaciation developed in the northern region of the cold, arid Russian Plain. Sediments of the Kasmalino suite accumulated in southwestern Siberia on the Priobye Plateau $(26,000 \pm 800$ $\mathrm{BP}, \mathrm{MGU}-233 ; 31,000 \pm 800 \mathrm{BP}, \mathrm{MGU}-203$ ); a cool, humid climate prevailed, where vegetation development was marked by spruce forest migration from the Altai foothills to Siberian plains. Glaciation occurred in the Altai Mountains, with glacial advance to cols and formation of dammed reservoirs $(25,300 \pm 600 \mathrm{BP}, \mathrm{MGU}-\mathrm{IOAN}-65)$. Ice-free areas were occupied by tundra, tundrasteppe and forest-tundra vegetation.

We identified periods of increased precipitation, cooling and glaciation for the Tien Shan Mountains (20,280 $\pm 250 \mathrm{BP}, \mathrm{MGU}-251 ; 16,300 \pm 420 \mathrm{BP}, \mathrm{MGU}-350)$. A rise in the level of Issyk-Kul Lake to $1640 \mathrm{~m} \mathrm{msl}$ was followed by a sharp decline; terraces on the lake shore correlate with tills of the Choktal mountain glaciation. Similar lake level rise, fall, and terrace development are apparent at Chatyrkul Lake.

In Yakutia, more severe climatic conditions were present, but the peak of cooling was earlier, according to ${ }^{14} \mathrm{C}$ dating of sediments in the third terrace of the Aldan River $(35,300 \pm 1500 \mathrm{BP}$ : MGU-IOAN-123). At peak of cooling, tundra-steppe landscape dominated, and animals of the Upper Paleolithic (Late) complex (e.g., Mammuthus primigenins, Bison prisens deminutus) and the lemming fauna dominated among mammals. In the lower Primorye region, the peak of cooling was 
more recent, compared to intracontinental Siberia. ${ }^{14} \mathrm{C}$ results indicate that the period, $39-25 \mathrm{ka} \mathrm{BP}$, was relatively warm in this area; small- and broad-leaved forest species are evident.

Results from the MGU laboratory, confirmed by other laboratories, indicate that the second Late Pleistocene cooling on the Eurasian continent developed synchronously. Cooling was most apparent in the northern and eastern areas, and possibly the Russian Plain; the Altai Mountains had the most rigorous climatic conditions of the Pleistocene.

\section{LATE QUATERNARY SEA-LEVEL CHANGES IN THE FAR EAST}

Ancient shorelines reflecting Late Pleistocene and Holocene sea-level changes were discovered on the coasts and shelves of the Bering Sea, the Sea of Okhotsk and the Sea of Japan (Glushankova et al. 1983). In southern Chukotka, on the coasts of Krest Bay and Anadyr Lake, Kaplin (1980) traced a marine terrace 5-7 m high; it is a remnant of a large shallow-water lagoon or a heavily desalinized lake. A coastal scarp exposes rhythmically layered loam, sand and peat strata. ${ }^{14} \mathrm{C}$ dates demonstrate that the terrace formed from 8-5 ka BP (MGU-393, $-398,-321,-394,-342,-478$, -341). Formation of terraces on rivers of the southwestern Chukotka is correlated to the same time period (MGU-456, -457). Along with most dynamic coastal accumulative forms, the floodplain terraces formed at 4-2 ka BP, when sea level was close to the present level (MGU-201, $-529,-459$, $-386,-334,-385,-311)$.

In northern Chukotka, within the Primorye lowland (the Sea of Chukotka coast), no traces of the Holocene and Middle Wisconsin transgressions were found (Tarakanov et al. 1974). Here, deep unconsolidated sediments are present, with ice lenses and interbedded peat strata in the upper part. A peat sample dated the formation of this unit at 33,700 $\pm 880 \mathrm{BP}$ (MGU-338). In Primorye lowland hollows, the complex of alas sediments is widely developed, consisting of peat and sandy loams of vegetation detritus (including timber) and ice ( $5 \mathrm{~m}$ deep). Formation of the alas complex on the plain began ca. $8 \mathrm{ka}$ BP (MGU-273) and continues.

The presence of these continuous strata casts doubt on the contention that several Holocene transgressions occurred in the Primorye lowland. This is supported by data on the "Primorye section" in Chaun Bay. Toward the shore, a 20-m-thick sediment section contains birch detritus and bones dated from 30 to 7 or $8 \mathrm{ka} \mathrm{BP}$ (MGU-701, -727, -724, -725). Preservation of these strata and absence of scours argue against the occurrence of transgressions. It is possible that the Middle Wisconsin and Holocene terraces of Anadyr Bay in the southern region of Chukotka were uplifted by neotectonic movements.

A vast plain of alluvial, fluvioglacial and lake-glacial sediments is present on the coast of western Kamchatka (Vtiurin and Svitoch 1978). Relict shorelines and lagoon remnants run in narrow strips along the coast, separated from the Sea of Okhotsk by high bars. This belt of relict coastal forms in the dry part of the coast is limited by the $20-\mathrm{m}$ isohyet, and its width is $8-20 \mathrm{~km}$. Terraces, ancient beach ridges and cliffs are observed at 5-6 m, 10-12 $\mathrm{m}$ and 18-20 m elevation (Kaplin 1982). In some areas, erosional-lake deposits are incised into the $20-\mathrm{m}$ terrace, and are filled with vegetation detritus (Fig. 3); this organic detritus has been dated at 31-39 ka BP (MGU-151, -152, $-150,-60$; MGU-IOAN-28, $-68,-185$ ). From these dates, we conclude that the highest terrace (the same as the 20-30-m terrace of southern Chukotka) formed during Middle Wisconsin warming; pollen data support this conclusion. From coastal studies, we conclude that sea level, during the Middle Wisconsin interglacial, was $15-30 \mathrm{~m}$ lower than at present. It would follow, then, that the 20-m terrace of western Kamchatka was uplifted $40-50 \mathrm{~m}$ by tectonic movements. 
The 5-6-m-high shoreline is represented on the coast by a series of beach ridges built from fresh and saltwater diatoms. The beach ridges formed probably during the lagoon coastal regime, when the Flandrian transgression intruded into lowland depressions.

These shoreline and lagoonal sediments correlate with the formation of coastal peat deposits, which are widespread in eroded scarps, river banks and lagoon shores along the coast of western Kamchatka. The episode of peat formation dates from 10-11 ka BP to the present (MGU-6, -5, -4, -10, $-149,-140)$. Basal peat layers and underlying eroded continental sediments are beneath present sea level.

Peat areas cover the surface of the 20-m terrace (Fig. 3). The peat sediments dated at $c a .10 \mathrm{ka}$ $\mathrm{BP}$ are gradually sinking below the sands and shingles of the barrier beach, and then beneath sea level. If we extrapolate this process to the upper part of the shelf, one can assume that peats should occur below recent marine sediments to $30-40 \mathrm{~m}$ below sea level. Drilling at this depth did actually expose the peats. Hence, in the Early Holocene, the coast and shelf from the surface of the $20-\mathrm{m}$-high terrace to $30 \mathrm{~m}$ below sea level were covered by peat. The shoreline was at the current $30-40-\mathrm{m}$ isobath. This agrees with the general understanding of the evolution of the Flandrian transgression.

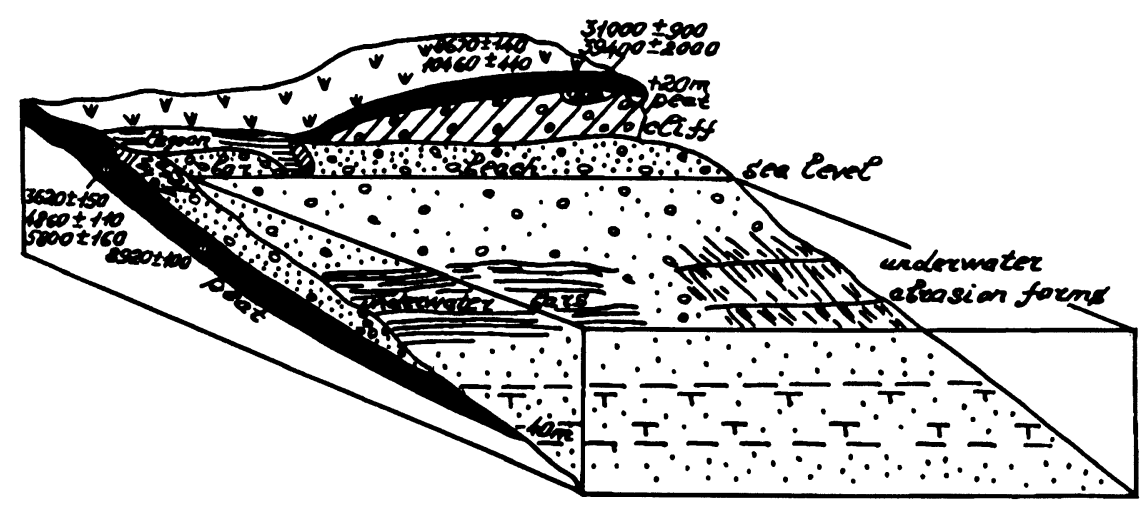

Fig. 3. Structure of the western Kamchatka coast

Terraces of varying height $(12-15,30,80,120 \mathrm{~m})$ and uncertain origin are present on the coast of Sakhalin Island. Sediments covering the projecting base of the 50-60 m terrace were assigned minimum dates of $>40 \mathrm{ka}$ BP (MGU-650, -653), suggesting Sangamon age of the abrasion (?) surface. Sediments of the 12-15-m terrace have been dated at 28-37 ka BP (MGU-651, -656), indicating that the terrace formed in the Middle Wisconsin and is synchronous with the 20-m western Kamchatka terrace.

A thick stratum of coastal and lagoon sediments is present on the Sakhalin coast, from 8-10 m below sea level to 7-9 $\mathrm{m}$ above present sea level. ${ }^{14} \mathrm{C}$ dates indicate continuous accumulation of these sediments from $9 \mathrm{ka}$ BP until present (MGU-604, -875, -882, -814, -580, -941, -579, -578).

The most comprehensive data on Late Pleistocene events are available for the continental coast and shelf of the Sea of Japan. In the Zolotoy Rog, a gulf isolated from wave action, a borehole exposed a section that is clearly divided into three sedimentation phases (Fig. 4). Marine sediments are present in the lower horizon; deep-water facies are replaced by shallow-water facies going upward in the section. We infer, from foraminifera and pollen spectra, that a warm, humid climate 
prevailed during accumulation of the shallow-water facies. The marine horizon is overlapped by continental sediments that contain a peat lens dated at 29,000 $\pm 250 \mathrm{BP}$ (MGU-325). Pollen and spore data indicate that continental sediments accumulated in a cool and dry climate. Higher in the section, marine sediments are present, but they were deposited in a climate close to that of the present. The upper horizon of the described sediments is Holocene; the middle corresponds to the second Würm (Wisconsin) maximum. Lower shallow-water sediments were deposited, apparently, during the middle Wisconsin marine transgression; ${ }^{14} \mathrm{C}$ results indicate that this occurred earlier than $29 \mathrm{ka}$ BP. Sediment cores indicate that the transgression maximum in the region south of Primorye reached to $-16 \mathrm{~m} \mathrm{msl}$.

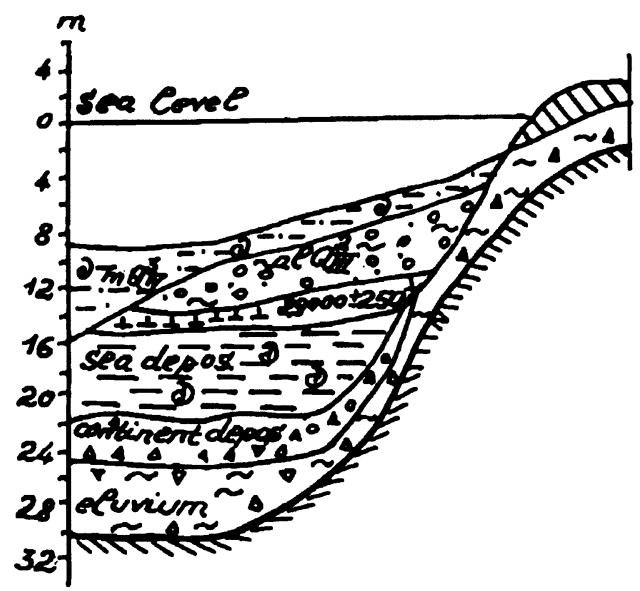

Fig. 4. Schematic section of sediments in bays of Primorye
Drilling of shelf deposits in the Sea of Japan near the Primorye coast has revealed relicts of ancient accumulative forms: bars that separated lagoons when sea level was lower (Fig. 5). Three lagoon-bar horizons were discovered that extend at least $500 \mathrm{~km}$ along the shore (Vnuchkov et al. 1976). The upper and middle horizons are most extensive, with lower horizon sediments occurring locally. The humic-acid fraction from lagoon silts and non-recrystallized carbonates from mollusk shells were ${ }^{14} \mathrm{C}$-dated to define the ages of these relict horizons. Unfortunately, it was impossible to date the lower horizon of the lagoonal sediments. The middle horizon was dated at $>42$ ka BP (MGU-307), >38 ka BP (MGU-305) and $26,740 \pm 400$ BP (MGU-306). Clearly, this bar and lagoon represent the Middle Wisconsin sea-level maximum. Pollen spectra reveal a dominance of broad-leaved species, indicating a warm climate during formation of these sediments. The upper beach barrier-lagoon sediment horizon formed in the Holocene (7-8 ka BP; MGU-63, -739, -822, -830 ) and fixes one phase of the post-Wisconsin Flandrian transgression.

A complex stratigraphic sequence formed over the Primorye shelf during the Flandrian transgression (Fig. 6), which includes: 1) coarse clastic sediments of relict bars and barriers; 2) silty lagoon sediments; and 3) alluvial-deltaic and estuarine-deltaic sediments. Marine waters penetrated toward land areas along valleys deepened in the Pleistocene, and formed a series of ingression bays

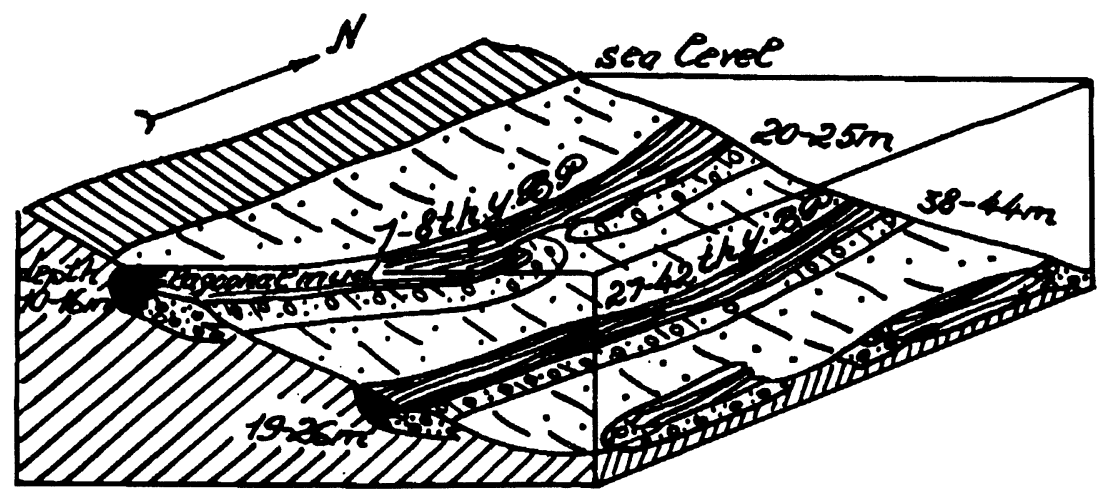

Fig. 5. Pattern of ancient coastlines and lagoonal sediments at the upper shelf of the Sea of Japan (sedimentary cover removed) 


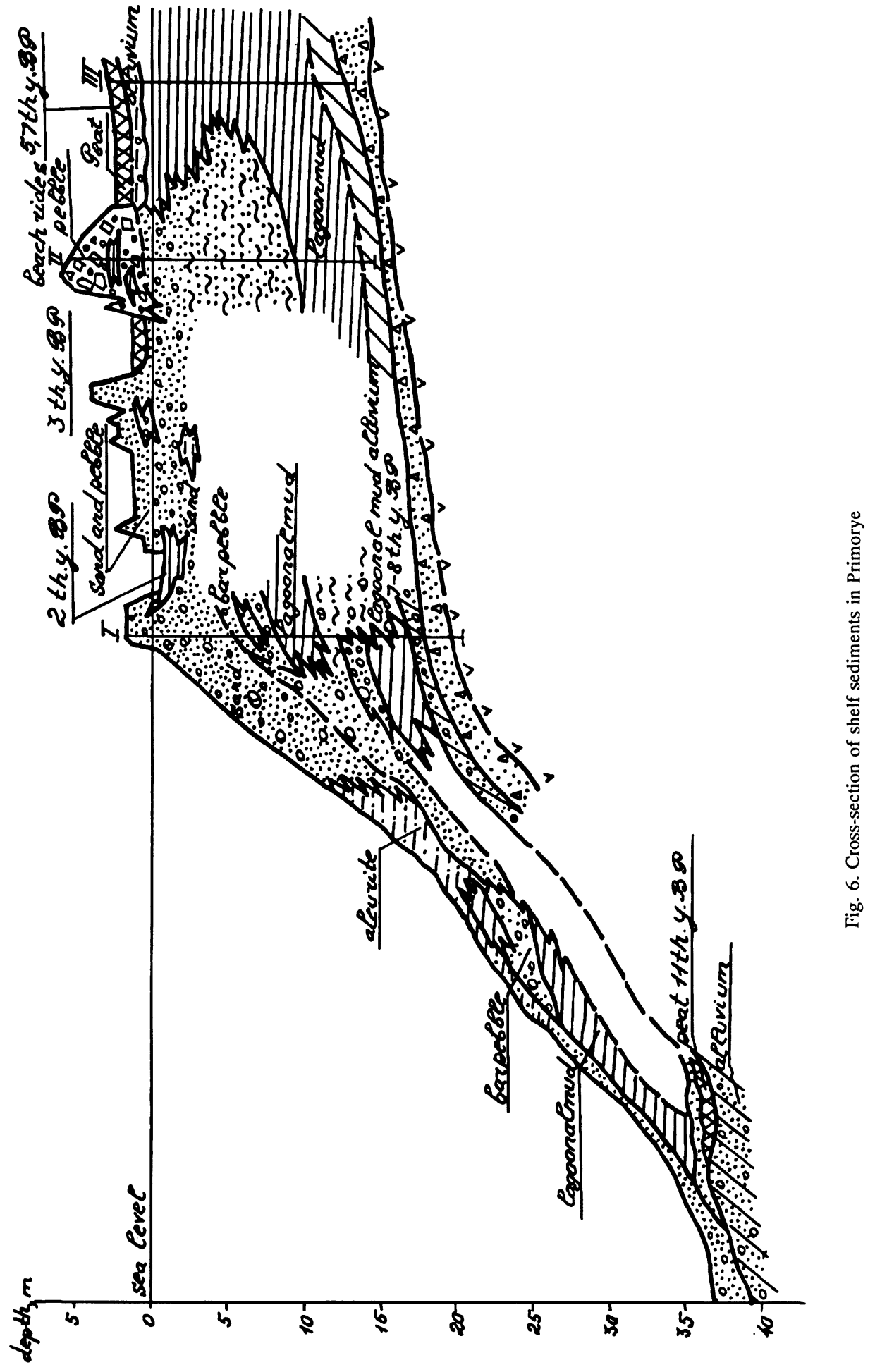


along the Primorye coast. Borehole data from the Nadhodka Gulf indicate that, in the Middle and Late Holocene, these bays were separated from the Sea of Japan by beach barriers and were filled by lagoonal and terrigeneous sediments. The head of this gulf is filled with sediments of a low accumulative terrace. At 9-17 $\mathrm{m}$ depth below the terrace surface, a marine mollusk sediment horizon was dated at $5790 \pm 110 \mathrm{BP}$ (MGU-263), $6260 \pm 110 \mathrm{BP}$ (MGU-266) and $6790 \pm 90 \mathrm{BP}$ (MGU-264). With decreasing depth, a transition is observed from marine to lagoon to continental sediments.

The Middle Wisconsin transgression created a terrace in southern Chukotka as high (20-30 m) as that in western Kamchatka. In Primorye, this transgression only rose to -16 to $30 \mathrm{~m}$, whereas in northern Chukotka, no traces of it were observed. The Holocene Flandrian transgression, on the other hand, created terraces higher than present sea level in Primorye and southern Chukotka, whereas sea level did not rise above the present shoreline on the Chukchi Sea coast and in western Kamchatka. This suggests the existence of different tectonic regimes on the far eastern coasts.

\section{REFERENCES}

Arslanov, Kh. A., Gai, N. A., Izmailov, Ya. A., Lokshin, N. V., Gerasimova, S. A., Tertychnyi, N. I. 1983 On the age and climatic conditions of sediment formation over the Late Pleistocene marine terraces on the coast of the Kerch strait. Chronicle Leningradskogo Universiteta, Geologiya, Geografiya 12(2): 69-79.

Balabanov, I. P. and Izmailov, Ya. A. 1989 Reconsideration of data on chronology of the Late Pleistocene and Holocene of the Azov-Black Sea basin. In Geochronology of the Quaternary Period. Tallinn: $42 \mathrm{p}$.

Glushankova, N. I., Parunin, O. B., Selivanov, A. O., Shlukov, A. I. and Timashkova, T. A. 1983 Moscow MV Lomonosov State University radiocarbon dates II: Sea level indicators from coastal USSR. Radiocarbon 25(3): 892-898.

Kaplin, P. A. 1982 Sea level changes in the far eastern seas of the USSR in the Pleistocene and Holocene. In Colguhoun, D., ed., Holocene Sea Level Fluctuations: Magnitude and Causes. Columbia, University of South Carolina Press: 96-103.

Kaplin, P. A., ed. 1980 Most Recent Sediments and Paleogeography of the Pleistocene on Chukotka. Moscow, Nauka: 294 pp.

Nevesskaya, L. A. 1965 Late Quaternary bivalve mollusks of the Black Sea, their systematics and ecology. Trudy Paleontologicheskogo Instituta Akademii Nauk SSSR 105. Moscow, Nauka: 391 p.

Semenenko, V. N., Kogomijieva, E. I. and Kovalyukh, N. N. 1976 Absolute dating with ${ }^{14} \mathrm{C}$ and correlation of marine Upper Pleistocene sediments of the Ukrainian SSR and People's Republic of Bulgaria. In Chetvertichnyi Period 16. Kiev, Naukova Dumka: 97-102.

Tarakanov, L. V., Kaplin, P. A. and Kursalova, V. I. 1974 The structure and absolute age of recent sediments of the Valkarai Lowland (northern Chukotka). Doklady Akademii Nauk SSR 216(5): 1128-1130.

Vnuchkov, V. A., Kaplin, P. A. and Shliukov, A. I. 1976 Ancient shorelines on shelves of the Sea of Japan. Doklady Akademii Nauk SSR 228(4): 914916.

Vtiurin, B. I. and Svitoch, A. A., eds. 1978 Most Recent Sediments and Paleogeography of the Pleistocene in Western Kamchatka. Moscow, Nauka: 121 pp. 